\title{
Strategi Memanfaatkan Rasa Senang Anak Bersekolah (Studi Berdasarkan Tingkat Pendidikan Orang Tua di Pangkalan Bun)
}

\author{
Muslimah
}

IAIN Palangka Raya, Email: muslimah.abdulazis@iain-palangkaraya.ac.id

\begin{abstract}
ABSTRAK
Penelitian ini bertujuan untuk menganalisis bagaimana penerimaan anak mengawali bersekolah; dan bagaimana strategi orang tua mempertahankan rasa senang anak awal bersekolah. Penelitian kualitatif ini digali melalui teknik observasi mendalam mengacu pada fokus penelitian sebagai pedoman observsi kepada orang tua dalam memanfaatkan rasa anak bersekolah; dan wawancara kepada orang tua selaku subjek penelitian juga kepada anak selalu informan dan subanalisis penelitian tentang penerimaan anak bersekolah dan kiat-kait orang tua memanfaatkan rasa senang anak bersekolah; serta dokumentasi keluarga untuk melihat usia lahir anak. Dianalisis secara sistematis melalui teori berkenaan dengan pedagogik dan psikologi. Temuan penelitian menunjukkan: semua anak memiliki penerimaan yang sama, yaitu merasa senang awal bersekolah formal di SD; strategi orang tua berpendidikan SLTA dan sarjana memanfaatkan dan mengondisikan secara sadar rasa senang anak bersekolah; dan orang tua berpendidikan SLTP menyerahkan kepada anak melalui bimbingan guru; serta orang tua berpendidikan SD menyerahkan sepeuhnya kepada anak tanpa bimbingan.
\end{abstract}

Kata kunci: anak senang ke sekolah, orang tua, memanfaatkan

\begin{abstract}
This study aims to analyze how children's acceptance begins school; and how parents' strategies to maintain the fun of children early in school. This qualitative research was explored through indepth observation techniques refers to the fokus of the study as a guide to observation to parents in utilizing children's sense of schooling; and interviews with parents as research subjects, and also to children as informants and subanalysis of research on the acceptance of children attending school and parents' tips in utilizing the joys of children attending school; and family documentation to see the child's age of birth. This research is analyzed systematically through theories relating to pedagogy and psychology. The research findings show: all children have the same acceptance, that is; feeling happy when starting formal schooling in the elementary school; the strategy of parents with high school education and scholars who is using and conditioning consciously the joys of children in school; and parents who have junior high school education submit to children through teacher guidance; and parents who have an elementary school education fully surrender to children without guidance.
\end{abstract}

Key words: children like to go to school, parents, advantage

Article History:

Received : 28-06-2020

Revised : 28-07-2020 


\section{PENDAhUlUAN}

Manusia itu lahir, yang berlangsung dalam ranah pendidikan informal dan berlangsung sepanjang hayat (Wahyuni, 2017). Seiring bertambahnya usia dan kematangan, anak membutuhkan pendidikan yang lebih luas dalam ranah pendidikan formal. Pendidikan formal di Indonesia dimulai dari tingkat SD (Mariyati, 2017), dan ini merupakan usia wajib belajar bagi anak Indonseia sampai SMP/MTs. Sayangnya masih banyak orang tua yang belum memahami jika anak yang akan memasuki sekolah formal pertama harus memiliki persiapan, sebagaimana penelitian (Sulistiyaningsih, 2005) bahwa hanya sedikit anak yang siap secara psikis. Kesiapan secara psikis di antaranya adalah memiliki penerimaan positif yang diekspresikan dengan rasa senang, dan orang tua berkewajiban mendampingi anak dengan mempertahankan rasa senang anak ketika akan masuk sekolah dan selama proses bersekolah, termasuk pada jenjang SD.

Penelitian ini mengambil data pada moment awal anak bersekolah di SD karena merupakan tingkatan pertama berada di sekolah formal dan pada usia ini anak rata-rata berusia 7 tahun, yang merupakan usia golden ege yaitu pada rentan usia 0-8 tahun (Sofia, 2005). Penulis akan menganalisa secara sistematis bagaimana penerimaan anak memulai bersekolah dan bagaimana kiat orang tua mempertahankan rasa senang anak mengawali sekolah, yang difokuskan pada rumusan masalah bagaimana penerimaan anak mengawali masuk sekolah? Dan bagaimana strategi orang tua mempertahankan rasa senang anak awal bersekolah?.

\section{METODE}

Penelitian ini menggunakan pendekatan kualitatif, dengan maksud agar data yang digali secara natural apa adanya, disajikan dalam bentuk deskriptif dan dilakukan secara sistematis analitik. Penggalian data dilakukan melalui teknik observasi mendalam kepada subjek penelitian yang ditetapkan secara porvosive sampling, dengan kriteria: orang tua yang terdiri dari suami dan istri; berdomisili di kota Pangkalan Bun Kalimantan Tengah; memiliki anak usia masuk SD, berjenis 
kelamin laki-laki atau perempuan; sifatnya hanya mengenalkan, berlatar belakang SD/MI, SMP/MTs, sedangkan anak masuk SD SMA/MA, dan PT, berjumlah merupakan pembelajaran yang sudah sebanyak empat keluarga dari terpusat dan terfokus (Pratiwi, 2010) masing-masing tingkatan latar untuk perkembangan anak belakang pendidikan tersebut. Sejak selanjutnya. Berdasarkan hasil awal penggalian data sudah penelitian (Proyono, 2017) bahwa melakukan analisis sampai selesai masalah yang sering muncul ketika pembuatan laporan, dilakukan anak menghadapi masuk sekolah dengan sistematis dan analitik formal (SD) adalah masalah menggunakan teori pedagogie dan kemandirian, konsentrasi, relasi psikologi.

\section{HASIL DAN PEMBAHASAN}

Undang Undang Sistem Pendidikan Nasional Nomor 20 Tahun 2003 Pasal 5 ayat (1) menyebutkan bahwa "setiap warga negara mempunyai hak yang sama untuk memperoleh pendidikan yang bermutu", yang sasarannya adalah untuk mengembangkan potensi agar memiliki kekuatan spiritual keagamaan, pengendalian diri, kepribadian, kecerdasan, akhlak mulia, dan keterampilan diri anak (Pratiwi, 2010). Sebagai modal dalam menghadapi anak masuk SD adalah diperlakukan sesuai dengan sikapnya yang polos (Susanto, 2011).

Proses anak memasuki sekolah formal, membutuhkan persiapan fisik dan psikis. Jika anak masuk TK sosial, motivasi, skill menulis. Karena itu, orang tua diingatkan jika kesiapan anak memasuki sekolah itu penting (Sulistiyaningsih, 2005). Anak yang memiliki kesiapan cukup matang untuk bersekolah akan memperoleh keuntungan dan kemajuan dalam perkembangan selanjutnya.

Kesiapan

dimaksud menyangkut tidak hanya fisik, tetapi juga kesiapan psikis anak. Kesiapan psikis itu juga penting karena mempengaruhi bagaimana anak memandang terhadap dirinya dan orang lain (Hurlock, 1978). Sebagaimana dalam penelitian ini juga berkaitan dengan bagaimana orang tua memanfatkan rasa senang anak bersekolah sebagai bagian dari kesiapan yang menjadi modal dasar anak dan bagaimana orang tua 
memanfaatkan sumber daya yang ada pada anak dan di sekitar anak.

Subjek penelitian ini terdiri dari empat keluarga yang terdiri dari suami dan istri berdasarkan latar belakang pendidikan, sebagaimana tabel berikut:

Tabel 1

Subjek Penelitian Berdasarkan Latar Belakang Pendidikan

\begin{tabular}{rcc}
\hline No. & Inisial & Pendidikan \\
\hline 1. & $\mathrm{Hs}$ & $\mathrm{S}-1$ \\
2. & $\mathrm{Rh}$ & SLTA \\
3. & $\mathrm{Mm}$ & SLTP \\
4. & $\mathrm{Ka}$ & $\mathrm{SD}$ \\
\hline
\end{tabular}

Semua orang tua di atas mengungkapkan jika semua anak mereka merasa senang ketika mau masuk Sekolah Dasar (SD). Sungguhpun demikian, penerimaan masing-masing anak dan pemanfatan orang tua terhadap rasa senang anak mau bersekolah di SD berbeda-beda. Ada yang sudah mengondisikannya sejak anak masih di Taman KanakKanak (TK), ada juga yang mengondisikannya ketika menjelang anak masuk SD, dan ada juga ketika saatnya masuk SD. Perbedaan tersebut dipengaruhi beberapa faktor, termasuk tingkat pendidikan orang tua.

Semua orang tua juga mengaku jika rasa senang awal anak bersekolah di SD diiringi dengan kesiapan anak secara fisik dan peningkatan skill atau keterampilan yang menyangkut kemandirian personal. Misalnya melakukan tanggungjawab pribadi yang sederhana seperti: mandi, berpakaian, melepas pakaian, makan, mau tidur, dan buang air, dilakukan secara mandiri. Semua orang tua merasa terbantu dengan istilah "masuk sekolah", karena anak merasa tidak lagi bermain sebagaimana ketika di TK. Bagaimana peneriman masing-masing keluarga dan seperti apa orang tua memanfaatkan rasa senang anak bersekolah, sebagaimana deskripsi berikut:

\section{A. Penerimaan Anak Mengawali Masuk Sekolah}

Anak berinisial PP dari keluarga $\mathrm{Rh}$ yang berpendidikan menengah atas terlihat sangat bergembira mendengar informasi jika masuk SD bulan depan. Orang tua sepakat memilih di Sekolah Islam Terpadu (SDIT), karena selain dekat dengan rumah yaitu berjarak kurang lebih 50 meter sudah sampai ke sekolah. Selain itu juga karena dua kakaknya sudah duluan bersekolah di sekolah tersebut. 
Keberadaan dua kakanya juga memotivasi rasa senang PP masuk SD. Ketika penulis menanyakan bagaimana kesan dan harapan PP menjelang masuk SD, dengan gembira dan optimis menjawab setiap pertanyaan dan sesekali disela kakak-kakaknya yang ikut serta bergembira karena adiknya sebentar lagi bersekolah dengan mereka di sekolah yang sama.

Sebagai bukti kegembiraan PP akan masuk SD, dia menunjukkan semua seragam termasuk seragam merah putih lengkap dengan atributnya seperti topi, dasi, tas dan alat tulis yang sudah dipersiapkan. Orang tua mengaku memang menyiapkan jauh sebelum waktunya masuk sekolah, karena merasa anak mereka banyak (empat orang) sehingga harus mendahulukan kepentingan anak dan merasa ada sebuah kewajiban yang terselesaikan hubungannya dengan biaya pendidikan anak. Setelah urusan pengeluaran untuk sekolah anak diselesaikan, mengaku ringan dan akan menyiapkan untuk keperluan yang lain. Selain itu oang tua mengatakan: mulai anak pertama sampai ketiga ini kami selalu menyediakan peralatan sekolah lebih awal, supaya anak semangat masuk sekolah, dan menghargai motivasinya untuk memulai sekolah. Ini kami lakukan karena melihat kegembiraan dan semangat anak yang mau masuk SD (W. Istri Rh, Minggu: 25 Mei 2019).

Pernyataan istri $\mathrm{Rh}$ di atas menunjukkan jika orang tua menghargai terhadap respon yang ditunjukkan oleh anak. Ketika penulis mengonfirmasinya kepada bapak $\mathrm{Rh}$, mengaku jika sangat terbantu dengan anak pertama dan kedua mereka yang menransferkan semangat kepada adiknya, sehingga orang tua hanya menyambutnya saja, anakanak yang saling memberi semangat, dan dari semangat ini menjadikan anak-anak mereka senang mengawali sekolah di SD. Sebagai bukti ketiga anaknya bergembira memulai sekolah di $\mathrm{SD}$, dikatakan oleh bapak Rh jika hampir setiap hari anak-anak mereka menceritakan tentang sekolahnya yang sebentar lagi libur, setelah libur masuk tahun ajaran baru dan masuk SD bagi PP. 
Hal senada juga ditunjukkan oleh bapak Hs yang berlatar belakang pendidikan sarjana. Mengaku jika secara sadar sudah mengondisikan anak yang sedang di TK agar berfikiran positif ketika anak mau masuk SD. Orang tua membawa anak untuk mencari peralatan sekolah ke toko buku. Sengaja meminta anak untuk memilih alat tulis mana yang dihendaki. Jika ada yang dianggap orang tua tidak tepat atau kurang tepat, maka orang tua tetap memberikan pertimbangan-pertimbangan

dalam memilihnya. Misalnya, anak perempuannya yang sebentar lagi akan masuk SD menyukai buku yang bergambar, orang tua mengarahkan agar memilih gambar yang sesuai dengan usia anak, bukan gambar yang kesannya cocok untuk anak remaja.

Selama beberapa kali kunjungan penulis di rumah keluarga Hs, menyaksikan komunikasi aktif antara anak perempuannya yang berusia 7 tahun dengan bapak Hs beserta istri. Materi yang diobrolkan berkisar pada asyiknya masuk sekolah, dapat teman baru dan berseragam baru, ada upacara bendera, dan lain-lain. Anak Hs yang berisinisial PN selalu memulai bertanya. Sesekali juga direspon oleh istri $\mathrm{Hs}$ sebagai bentuk penghargaan dan memperhatikan terhadap pertanyaan-pertanyaan yang diungkapkan anak.

Bapak Hs mengatakan:

ketika dulu anak masuk TK juga kami perlakukan yang sama, yaitu melibatkan anak dalam mengadakan atau menyiapkan peralatan sekolahnya. Sekarang kami harus memiliki cara untuk menjadikan anak tetap semangat bersekolah. Selaku orang tua memang harus sabar membangunkan anak tidur di saat dia masih lelap menikmatinya. Melakukannya mesti bertahap sampai anak mandiri (W. Bp Hs, Minggu: 25 Mei 2019).

Ungkapan yang disampaikan bapak Hs di atas menunjukkan jika orang tua sengaja melakukan hal-hal yang membuat anak merasa memiliki dengan yang akan dilakukan anak yaitu bersekolah di SD. Selain itu, penulis juga melihat kekompakan suami dan istri dari keluarga $\mathrm{Hs}$ dalam mendidik anak, termasuk 
kompak dalam menjadikan anak tetap semangat dan gembira menyambut sekolahnya akan naik tingkat dari TK ke SD. Terlihat dari bagaimana mereka berkomunikasi dengan anak dan melibatkan anak secara langsung terhadap keperluan pribadi anak.

Penulis menyaksikan anak yang meminta ditemani ibunya menyusun buku-buku yang dibeli pada beberapa waktu yang lalu bersama orang tuanya (O. Keluarga Hs, Minggu: 25 Mei 2019). Orang tua secara bergantian melalui bahasa isyarat jika istri yang menemani penulis ngobrol dan bapak Hs yang menemani anak bermain. Selain itu, penulis juga menyaksikan jika anak mereka bertanya kepada orang tuanya yang sedang menerima penulis bertamu, orang tua juga selalu meminta izin untuk sejenak merespon keinginan anak yang minta dijawab atau minta direspon dengan perbuatan tertentu yang diinginkan anak.

Perbuatan yang ditunjukkan bapak Hs beserta istri menunjukkan jika secara sadar membersamai anak bermain dan belajar, yang dalam proses bermain ada belajar dan dalam belajar sambil bermain serta mendahulukan kepentingan anak. Hal ini wajar dilakukan keluarga Hs karena ditunjang oleh latar belakang pendidikan mereka yang sama-sama sarjana keguruan dan sering mengikuti parenting. Selain itu, juga didukung oleh pekerjaan yang sama-sama sebagai guru. Guru di Sekolah Dasar bagi istri Hs dan guru Sekolah Menengah Pertama (SMP) bagi bapak Hs. Kompetensi pedagogik yang dimiliki secara teori benar-benar terlihat dan terasa diimplementsikan melalui praktik mendidik anak, termasuk mengondisikan anak sebelum masuk sekolah yang menjadi usia wajib belajar yaitu masuk SD.

Sedikit berbeda dengan keluarga $\mathrm{Mm}$ yang suami istri sama-sama berpendidikan SMP. Mengaku jika biasa saja dalam menghadapi anak yang mau masuk SD, dengan alasan karena yakin anak sudah tau jika dia mau masuk SD karena sebentar lagi tamat TK. Sebagaimana pernyataan istri $\mathrm{Mm}$ bahwa:

dia anak bungsu dan hanya dia yang sempat bersekolah 
mulai TK, kakak-kakaknya semua langsung masuk SD. Jadi, dia sudah tau dari gurunya di TK jika masuk $S D$ dan meninggalkan TK. Sekarang sudah tidak susah masuk SD karena semua seragam sudah disediakan sekolah, kami tinggal menuliskan ukuran baju dan bayar (W. Istri Mm, Minggu: 01 Juni 2019).

Istri $\mathrm{Mm}$ menceritakan pengalaman dua anak sebelumnya yang tidak pernah belajar di TK, mengharuskan orang tua untuk mengenalkan jika anak akan masuk SD, tetapi anak ketiga yang sedang bersekolah di TK, sudah mengetahui jika akan melanjutkan ke SD yang lokasinya berdekatan dengan TK dan dekat dengan rumah, sehingga orang tua tidak memiliki kiat khusus dalam memberitahukan jika anak akan melanjutkan sekolah ke SD.

Anak keluarga $\mathrm{Mm}$ yang berinisial Yn tetap mengaku senang karena sudah duduk di bangku SD. Pengakuannya dalam bahasa yang sederhana menunjukkan jika dia mulai belajar dengan waktu yang lama, tidak lagi diantar dan dijemput ibu atau kakaknya, dia juga harus datang tepat waktu dan tidak boleh terlambat karena takut dihukum. Pernyataan anak ini menunjukkan jika sudah mengerti dengan aturan yang berlaku di $\mathrm{SD}$, juga ada batasan yang apabila dilanggar menjadikannya dihukum. Artinya, dia harus sungguh-sungguh menjalani sekolah di SD yang berbeda dengan TK.

Istri

$\mathrm{Mm}$ juga

mengungkapkan jika terjadi perubahan yang besar dengan anaknya ketika awal masuk SD minggu sebelumnya. Mengaku jika anaknya semanagt bangun bagi dan tanpa dibanguni, ketika bangun langsung mandi untuk persiapan berangkat sekolah. Sebagai penghargaan dari orang tua, rela memberikan uang jajan setiap hari Rp.10.000. Padahal selama di TK tidak pernah dibekali uang jajan karena tidak dibolehkan oleh sekolah, baru seminggu sekolah di SD sudah banyak uang jajannya.

Keluarga $\mathrm{Mm}$ menganggap tidak masalah dengan besarnya uang jajan yang diminta anak setiap berangkat sekolah. Menganggap jika itu memang harus diberikan. Selain karena 
anak sudah tau menggunakan uang jajan, juga karena banyak yang jualan, dan merasa kasihan jika anaknya berkeinginan sementara tidak ada uang di tangan. Besarnya uang jajan bagi anak mereka bukan menjadi beban yang dikhawatirkan justru dianggap sebagai penyemangat anak mereka yang sudah bersekolah di SD.

\begin{tabular}{lrrr}
\multicolumn{2}{c}{ Berbeda lagi } & dengan \\
keluarga Ka yang & berlatar \\
belakang & pendidikan & SD.
\end{tabular}
Mengaku jika anak kedua mereka pernah bersekolah di TK tetapi tidak rutin turun ke sekolah. Orang tua mengaku tidak mau memaksa anak, tetapi diserahkan kepada maunya anak, dengan maksud jika anak sudah besar pasti bisa menilai sendiri mana yang baik dan mana yang tidak baik. Padahal sudah dibuktikan melalui penelitian bahwa sangat signifikan perbedaan kemandirian anak yang sebelumnya sudah bersekolah di TK dengan yang tidak bersekolah di TK ketika masuk SD. Anak yang sudah bersekolah di TK lebih percaya diri, lebih optimis, lebih mandiri dan lebih mudah mengikuti setiap tahapan pembelajaran yang diberikan ketika masuk SD (Halimah dkk, 2010).

Anak keluarga $\mathrm{Ka}$ tetap menyelesaikan pendidikan di TK dan memiliki ijazah yang ditunjukkan dengan penulis, bersampul warna hijau dan bertuliskan nilai-nilai dalam bentuk angka juga deskriptif dengan predikat baik. Anak mereka yang berinisial MA menyadari jika sekarang dia tidak lagi bersekolah di TK, tetapi sudah bersekolah di SD Negeri yang tidak terlalu jauh dari rumahnya. Bersama ibunya mendaftar masuk SD sejak bulan Juni 2019 dan sudah memiliki semua seragam SD.

Perbedaan dengan anakanak lainnya yang penulis teliti, bahwa anak keluarga $\mathrm{Ka}$ mulai mengulang perbuatannya yaitu sering tidak turun ke sekolah pada hari aktif, yaitu hari Senin sampai dengan Sabtu sejak pukul 07.00 WIB sampai dengan pukul 11.00 WIB setiap harinya kecuali hari Jumat pulang pukul 09.00 WIB dan hari Sabtu pulang pukul 10.00 WIB, waktu yang seharusnya sekolah tetapi lebih 
suka digunakan untuk menonton televisi di rumahnya.

Keberadaan keluarga $\mathrm{Ka}$ yang berdomisili di pinggiran kota, dan pekerjaan orang tua yang setiap harinya bekerja di kebun sawit, menjadikan orang tua tidak dapat mengawasi anak mereka. Selain itu, penulis juga mengambil kesimpulan dari mengamati keseharian orang tua dan anak, yaitu tidak adanya punishment yang diberikan orang tua kepada anak jika melakukan perbuatan yang tidak seharusnya. Misalnya ketika penulis berada di rumah mereka pada hari Jumat dan menjelang shalat Jumat, orang tua sama sekali tidak mengingatkan jika harus shalat Jumat. Demikian juga dengan bapak Ka yang juga tidak melaksanakan shalat Jumat.

Bapak Ka beserta istri mengaku tidak pernah marah dengan anak dan tidak pernah menghukum. Penulis mempercayai apa yang disampaikan oleh suami istri tentang hal ini, karena pada saat penulis berkunjung di hari yang lain, mendapati anak mereka MA menonton televisi dengan volume suara televisi yang tinggi. Karena sudah beberapa kali bertemu dan sudah terjalin keakraban dengan keluarga tersebut, penulis ikut mengingatkan jika harus mengecilkan suara televisi. Permintaan penulis tidak dihiraukan MA juga tidak didukung oleh bapak Ka beserta istri, padahal mereka mengetahui.

Dari beberapa informasi bagaimana orang tua dan anak menjalani aktivitas keseharian mereka, terlihat jika orang tua cenderung membiarkan, termasuk dalam mengikuti persekolahan sepenuhnya diserahkan kepada anak. Guru yang mengajar kelas I di sekolah tempat MA bersekolah mengatakan:

kami sudah tau saja dengan MA yang jarang sekolah saat di TK, juga sudah pernah saya ajak bicara empat mata. Saya rayu, beri pengertian tentang pentingnya sekolah. Baru sebulan sekolah sudah beberapa hari tidak masuk. Begini juga yang dialami Kakaknya saat di SMP dulu, saya tau karena suami saya mengajarnya (W. Guru SA, Sabtu: 07 Juni 2019).

Pernyataan Guru di atas menguatkan hasil pengamatan yang penulis dapatkan jika anak 
belum merubah kebiasaanya saat masih di TK, dan ada upaya yang dilakukan guru di atas untuk mengubahnya. Pernyataan di atas juga menguatkan jika contoh yang didapat dari anak yang lebih tua sangat berpengaruh kepada anak berikutnya. Artinya, anak yang berasal dari keluarga berlatar belakang pendidikan SD menganggap jika masuk SD merupakan hal biasa dan tidak memiliki sesuatu yang dianggap baru dalam proses persekolahan.

Berdasarkan deskripsi di atas, menunjukkan bahwa semua anak merasa senang untuk mengawali bersekolah di SD yang merupakan usia wajib belajar, sebagaimana diatur dalam Peraturan Menteri Pendidikan Nasional Republik Indonesia Nomor 19 Tahun 2007 adalah anak usia 6-7 tahun. Rasa senang anak ditandai dengan selalu bertanya tentang sekolah yang akan menjadi tempat sekolahnya seperti yang ditunjukkan anak keluarga $\mathrm{Rh}$, dikatakan oleh Aisyah (2010) memang merupakan ciri dari kematangan anak yang akan bersekolah secara formal, yaitu di SD adalah merasa senang mengawalinya.

Anak yang ketika sejak TK sudah ditanamkan oleh orang tua pentingnya bermain sambil belajar, didukung dengan perilaku konsisten orang tua yang memberikan support dengan kerelaan hati untuk mengantar dan menjemput serta melakukan pengawasan kepada anak, menghasilkan sikap yang konsisten juga ditunjukkan oleh anak. Sebaliknya orang tua yang tidak menganggap penting bermain dan belajar ketika TK, maka juga ditunjukkan anak dengan tidak menganggap penting sebagaimana yang ditunjukkan oleh anak dari keluarga Ka yang menyerahkan sepenuhnya kepada anak tanpa pengarahan sebagai rambu-rambu yang harus dipedomani anak dalam bersikap. Hal ini tidak ada perbedaan antara anak laki-laki dengan anak perempuan (Mariyati, 2016).

Anak yang terbiasa belajar pada usia prasekolah yaitu ketika berada di TK, menjadikan peluang bagi orang tua untuk mengembangkan rasa berkuasa anak (Muslimah, 2015), karena 
sudah memiliki informasi yang positif tentang kelanjutan sekolahnya setelah menamatkan TK. Sekolah di SD merupakan momen yang ditunggu-tunggu oleh anak yang sudah terbiasa dengan penerimaan yang baik terhadap sekolah. Anak mulai mengerti jika SD merupakan sekolah formal yang memang sudah menegakkan aturan dan batasan, berbeda dengan ketika masih di TK yang bermain sambil belajar dan masih ditoleransi tentang banyak hal oleh orang dewasa di sekitanya.

Anak juga memahami jika usia SD sudah harus sungguhsungguh belajar. Anak yang komitmen memulai sekolah di SD dengan keyakinan yang positif, megenai kemampuannya untuk mengikuti kegiatan-kegiatan yang ada di SD menjadi sumber daya yang berpengaruh positif terhadap diri anak dan dampaknya terhadap upaya yang dilakukan orang tua. Clemes (1980) berpendapat bahwa ketika awal bersekolah, semua anak meyakini jika mereka harus berusaha terhadap apa yang dipersyaratkan untuk mereka. Anak berfikiran bahwa mereka akan mendapatkan keberhasilan jika diiringi dengan kesungguhan.

Berdasarkan pembahasan penerimaan anak terhadap awal bersekolah di atas dapat diketahui bahwa semua anak menunjukkan penerimaan yang sama yaitu merasa senang terhadap awal bersekolah. Dalam pelaksanannya ditunjukkan oleh anak dari keluarga berpendidikan SLTA dan S-1 dengan menunjukkan rasa ingin tau yang tinggi, dan anak dari keluarga berpendidikan SLTP dan SD hanya mengikuti aktivitas keseharian sebagaimana ketika masuk TK.

Terdapat motif-motif yang dapat memberikan pengaruh terhadap penerimaan anak yang berasal dari keyakinan dan perasaan anak tentang dirinya termasuk memulai bersekolah. Pertama, anak akan berfikiran dan bertindak sebagaimana cara yang dapat meningkatkan harga diri yang diinginkannya; kedua, anak akan bereaksi dengan cara mengonfirmasi konsep dirinya oleh orang lain; ketiga, anak melakukan reaksi yang dapat menahan citra dirinya secara 
konsisten, tanpa peduli dengan lingkungannya yang mungkin akan atau sudah berubah (Clemes, 1980).

Sebagaimana data penelitian ini, bahwa semua anak memiliki penerimaan yang senang awal bersekolah, berarti termasuk kekuatan yang bersumber dari intern anak. Dampaknya, anak akan memiliki motivasi yang kuat untuk sukses dengan yang dijalaninya bersekolah sejak awal sampai akhir targetnya. Jika dihubungkan dengan pendapat di atas, berarti termasuk dalam motif yang pertama yaitu anak akan bertindak dengan cara yang dapat meningkatkan harga dirinya.

Orang tua yang mengetahui jika peneriman anaknya bersekolah berada pada ranah positif, seyogyanya meresponnya dengan sikap konsisten memberikan motivasi agar anak tetap senang melakukannya dan melakukan pengawasan sebagai bentuk perhatian kepada anak serta menerapkan reward sebagai umpan balik terhadap sikap positif yang ditunjukkan anak yaitu senang bersekolah.
Pengaruh keteladanan saudara tertua anak yang menjadikan anak merasa senang bersekolah diketahui oleh (Mingming, 2017) melalui hasil penelitiannya bahwa komunikasi yang sehat dan pendidikan yang tepat meningkatkan kesehatan psikologis anggota keluarga sebagai modal awal dan saling merespon positif anggota keluarga.

Berdasarkan pembahasan di atas diketahui bahwa semua orang tua merasakan jika anaknya memiliki penerimaan yang positif terhadap sekolah sejak awalnya dan merasa senang meyambut momen awal bersekolah. Ini merupakan motivasi intern yang menjadi kekuatan awal bersekolah.

B. Strategi

Orang Tua Mempertahankan Rasa Senang Anak Awal Bersekolah

Keluarga bapak Hs yang berlatar belakang pendidikan sarjana keguruan menyebutkan jika anak memiliki semangatnya turun naik. Seiring dengan itu, juga turun naik kegembiraan yang anak rasakan. Teori yang mereka 
dapatkan ketika mempelajari ilmu tentang pedagogik sangat terasa maknanya ketika mempraktikan pada anak sendiri. Menjadikan mereka harus kompak beserta istri dalam mendidik anak, termasuk dalam menjaga agar semangat anak tetap konstan.

Keluarga Hs mengaku jika selalu membersamai anak dalam belajar dan mengkhususkan waktu setelah shalat Maghrib sampai waktu shalat Isya untuk free aktivitas lain selain belajar membaca Al-Quran bagi anak yang baru masuk SD, karena harus tahsin atau memperbaiki bacaan Al-Quran dan menambah hafalan bagi anak pertama dan kedua mereka. Menjadikan anakanak mereka terbiasa memanfaatkan waktu tersebut untuk belajar, menyiapkan peralatan sekolah untuk besok dan menyelesaikan tugas termasuk jika ada Pekerjan Rumah (PR).

$$
\text { Kebiasaan yang sudah }
$$
dimiliki oleh saudara tua PN mempermudah orang tua mempertahankan rasa senang anak melaksanakan aktivitas belajar termasuk mempertahankan rasa senang anak menjalani persekolahan. Awal anak bersekolah di SD bukan hal yang sangat mengkhawatirkan bagi keluarga Hs karena dalam keseharian keluarga tersebut memang menjadi keluarga pembelajar, mulai dari bapak $\mathrm{Hs}$, istri, juga anak-anak termasuk anak yang baru masuk SD selalu akrab dengan dunia pendidikan. Buku dan kitab Al-Quran kecil selalu ada di tangan bapak Hs dan istri, menjadi teladan bagi anak-anak mereka untuk mempertahankan rasa senang belajar dan bersekolah.

Penulis juga menyaksikan jika keluarga Hs memfasilitasi sarana anak dalam bersekolah. Misalnya terdapat gambar-gambar yang mendukung agar anak selalu semangat sekolah. Ada jadwal belajar yang bergambar, ditulis oleh anak sesuai jadwal belajar masing-masing dan ditempel dibagian sisi dinding kamar rumah mereka. Secara berkala orang tua juga membelikan buku cerita sebagai pengganti tidak menonton televisi berlebihan. Mereka saling membaca dan 
terkadang juga penulis saksikan anak tertua membacakan buku cerita, sementara anak yang baru masuk SD menyimaknya. Penulis merasakan suasana yang edukatif dan religius dari keluarga Hs.

Upaya mempertahankan rasa senang anak untuk menuntut ilmu dengan bersekolah, khusus untuk anak yang kelas I SD mereka tetap diuntungkan dengan saudara tertua PN yang sudah memiliki kebiasan belajar. Ini menjadi modal orang tua untuk tetap menjaga semangat dan rasa gembira anak dalam bersekolah. Bapak Hs mengaku bahwa:

setiap pulang sekolah atau setelah shalat Mahgrib, semua anak terlebih yang baru masuk SD selalu ditanya bagaimana selama di sekolah tadi. Bahkan sebelum bertanya, anak menyampaikan duluan (W. Bp Hs, Minggu: 09 Mei 2019).

Kiat yang dilakukan oleh keluarga Hs merupakan upaya sadar yang menjadi komitmen bersama khususnya bersama istri dalam menjaga semangat dan rasa senang anak bersekolah. Mereka lakukan menggunakan metode keteladanan yang dimulai dari diri mereka selaku orang tua, dan diikuti anak-anak mereka dan dilakukan mulai dari anak pertama sampai dengan anak yang baru masuk SD. Sehingga menjadi sebuah kebiasaan bagi keluarga yang berlatar belakang pendidikan sarjana ini untuk selalu senang dalam menuntut ilmu dan bersekolah bagi anak mereka.

Demikian juga dengan keluarga $\mathrm{Rh}$ yang berlatar belakang pendidikan SMA. Juga merasa diuntungkan dengan kebiasaan anak pertama dan kedua mereka yang sudah terlebih dulu merasakan duduk di bangku SD sejak awal bersekolah. Terkadang sang kakak berdua yang menceritakan dan bertanya sesuatu untuk meyakinkan apakah PP juga mengalami seperti yang mereka alami ketika dulu awal bersekolah di SDIT. Misalnya bakal ada kunjungan ke PDAM (Perusahan Daerah Air Minum) Kumai. Betapa serunya penulis meyaksikan tiga saudara ini saling berbagi informasi.

Sedikit berbeda dengan anak dari orang tua yang berlatar 
belakang pendidikan SMP dan SD sebagaimana pernyataan berikut:

anak sudah tau apa yang dia lakukan, dia belajar hampir setiap malam, katanya ada PR dari gurunya. Belajarnya memang hanya sendiri, karena tidak ada lagi yang sekolah di rumah ini selain dia. Sesekali bisa juga dia bertanya dengan bapaknya (W. Istri Mm, Minggu: 09 Mei 2019).

terserah anak saja, Mas dulu juga begitu, sekarang bisa saja dia rajin sekolah. Bahkan saya minta tidak masuk sehari saat harus panen kemarin saja tidak mau, katanya di SMK sekarang tidak seperti di SD dulu (W. Bp Ka, Sabtu: 08 Mei 2019).

Kedua pernyataan di atas ada persamaan dalam hal upaya yang dilakukan orang tua, yaitu sama-sama mempercayakan kepada anak sepenuhnya. Hanya saja, karena anak yang berlatar belakang keluarga SMP memiliki habbit yang menyenangi dengan sekolah sejak TK, maka tetap terbawa dan senang bersekolah dan melaksanakan tugas-tugas sekolah ketika di rumah. Demikian juga dengan anak dari keluarga berlatar belakang pendidikan SD, upaya yang dilakukan dengan menyerahkan sepenuhnya kepada anak, ditunjukkan anak dengan tidak konsisten dalam bersekolah, maka ketika anak masuk SD pun juga menunjukkan sikap yang sama yaitu kurang menyenangi proses pelaksanannya. Orang tua yang menyerahkan sepenuhnya kepada anak tanpa menyadari proses pendidikannya, berarti telah melakukan kesalahan dalam pengasuhan anak, karena orang tua memang harus menyadari dan mengondisikan persiapan terhadap anak dalam memasuki pendidikan formal.

Seyogyanya selaku orang tua memiliki strategi mempertahankan rasa senang anak bersekolah, agar anak tetap berada dalam kondisi yang mendukung terhadap sekolah dan segala yang berhubungan dengan sekolah termasuk belajar di sekolah maupun di rumah sebagai outcome anak bersekolah di sekolah formal (SD). Sekolah juga menjadikan anak bertanggungjawab terhadap tanggungjawab personal yang sederhana seperti mandi, makan, berpakaian yang dilakukan secara 
rutin berulang-ulang. Berawal dari tanggungjawab personal seperti ini menjadikan modal bagi anak untuk mengembangkan nilai tanggungjawab yang lebih besar, serta perasaan gembira anak untuk terus mau bertanggungjawab terhadap urusan sekolah. Karena ini yang nyata-nyata ada pada mayoritas anak seusianya. Jika perasan senang melaksanakan sekolah sejak awal, berarti tanggungjawabnya untuk bersekolah sudah tertanam dalam diri anak, maka menjadi peluang bagi orang tua untuk meningkatkan terhadap tanggungjawab yang lebih besar.

Sikap senang bersekolah yang ditunjukkan anak karena ada motivasi dari orang tuanya sebagai respon balik setelah anak menunjukkan rasa senangnya dengan memenuhi sumber daya yang diperlukan anak, sebagai strategi untuk mempertahankan rasa senang anak, dalam hal ini termasuk motif yang kedua yaitu "motivasi eksternal anak", dalam hal ini adalah pengaruh yang ada di sekitar anak. Sebagaimana yang ditunjukkan oleh keluarga
Hs melalui komunikasi efektif dalam proses mempertahankan rasa senang anak, dengan komunikasi yang efektif akan terjadi argumentasi yang interaksif dan saling memberikan pengaruh positif antar anggota keluarga (Bova, 2016). Bahkan menurut (Michelle dkk, 2017) orang tua yang memiliki kecerdasan komunikasi dan mengomunikasikan dengan efektif kepada anak akan menjadikan anak juga memiliki kecerdasan dalam mentransfernya kepada yang lain, sebaliknya orang tua yang memiliki komunikasi yang rumit akan meningkatkan retensi/ penyimpangan akademik dari sisi kecerdasan informasi.

Selanjutnya orang tua yang tidak berhasil memanfaatkan stimulus anak yang awalnya menunjukkan rasa senang bersekolah, seperti yang terjadi dengan keluarga $\mathrm{Ka}$ juga dipengaruhi oleh faktor eksternal anak yaitu pengawasan orang tua, reward dan punishment orang tua yang lemah, serta keteladanan anak pertama yang kurang senang bersekolah. Seirama dengan pernyataan (Susanto, 2011) 
bahwa yang terpenting juga adalah segi fungsional. Ketika anak dan orang tua menganggap bahwa bersekolah adalah hal biasa saja, maka sikap yang dilakukanpun seirama dengan bagaimana orang tua dan anak berpandangan tentangnya.

Deskripsi data di atas juga menggambarkan tentang peran seorang ibu dan seorang ayah yang aktif mendampingi anak dalam level transisi yaitu dari TK yang merupakan pendidikan informal ke SD yang merupakan sekolah formal. Anak yang merasakan kehadiran orang tua dalam memberikan stimulus dan respon terhadap rasa senang yang ditunjukkan anak berdampak positif, menjadikan anak tetap dalam suasana yang senang menjalani sekolah formal (Proctor, 2019). Menjadikan orang tua sebagai tokoh kunci dalam mempertahankan rasa senang anak dengan memotivasi dan mempertahankan semangat anak bersekolah (Matthes, 2018).

Berdasarkan pembahasan di atas diketahui bahwa terdapat beberapa strategi yang dilakukan orang tua dalam mempertahankan rasa senang anak bersekolah, yaitu: orang tua berpendidikan tinggi dan menengah atas, secara sadar dan berkemampuan mengondisikan dan memotivasi anak untuk tetap senang bersekolah; orang tua yang berpendidikan menengah pertama menyerahkan sepenuhnya kepada anak melalui bimbingan guru; dan orang tua berpendidikan SD menyerahkan sepenuhnya kepada anak tanpa bimbingan.

\section{Kesimpulan}

Berdasarkan pembahasan di atas dapat diambil kesimpulkan bahwa:

1. Semua anak memiliki penerimaan yang sama, yaitu merasa senang dengan momen awal bersekolah formal di tingkat SD

2. Terdapat perbedaan strategi orang tua mempertahankan rasa senang anak pada awal bersekolah. Orang tua berpendidikan SLTA dan sarjana memanfaatkan dan mengondisikan secara sadar terhadap rasa senang awal anak bersekolah; orang tua berpendidikan SLTP menyerahkan kepada anak melalui bimbingan; dan orang tua yang berlatar 
belakang pendidikan

SD menyerahkan sepenuhnya kepada anak tanpa bimbingan.

\section{Daftar Pustaka}

Bova, A. (2016). The Interplay Between Parental Argumentative Strategies, Children's Reactions And Topics Of Disagreement During Family Conversations. Learning, Culture and Social Interaction.

https://doi.org/doi.org/10.1016 Li.lcsi.2018.05.003.

Clemes., Harris. (1980). How to Teach Children Responsibility. San Jose: Enrich. Proctor., Herlen. (t.t.). School and The Mass Production of Parenting Advice. British Journal of Educational Studies. https://www.tandfonline.com/loi /rbje20

Hurlock. E. B. (1978). Psikologi Perkembangan (5 ed.). Erlangga.

Matthes., Benjamin. (t.t.). Influence of Parents' Implicit Theories About Ability on Parents' LearningRelated Behaviors, Children's Implicit Theories, and Children's Academic Achievement. Journal: Contemporary Educational Psychology. https://doi.org/10.1016/j.cedps ych.2018.07.001

Michelle., Leichtman. D., dk. (2017). Talking After School: Parents' Conversational Styles and Children's Memory for A Science Lesso. Journal of Experimental Child Psychology. https://doi.org/www.elsevier.co $\mathrm{m} /$ locate/jecp

Mariyati., Lely Ika. (2016). Usia dan Jenis Kelamin dengan Kesiapan Masuk Sekolah Dasar. Prosiding Seminar Nasional Psikologi UMG.
Mariyati. (2017). Usia dan Jenis Kelamin dengan Kesiapan Masuk Sekolah Dasar. Seminar Nasional Psikologi UMG. Fakultas Psikologi Universitas Muhammadiyah Sidoarjo ikalely@yahoo.co.id.

Mingming. (2017). Does Children's Education Matter for Parents' Health and Cognition? Evidence From China. SEJ, 7(4).

Muslimah. (2015). Penanaman Nilai Religius Dalam Keluarga. Antasari Press.

Pratiwi., Wiwik. (2010). Analisi Pelaksanaan Permainan Kreatif dalam Mengembangkan Kemampuan Kognitif pada TK Pusat PAUD Renggang Kecamatan Bajeng Barat Kabupaten Gowa. Tesis PPs UNM Makassar.

Proyono,. Muhammad Nur. (2017). Kemampuan Problem Solving Dengan Kesiapan Masuk Sekolah Dasar. Psikologia, 2(1), 38-51. https://doi.org/Link:

10.21070/psikologia.v2i1.1267

Sofia, H. (2005). Perkembangan Belajar Pada Anak Usia Dini (Depdiknas).

Sulistiyaningsih, W. (2005). Kesiapan Bersekolah Anak Ditinjau dari Jenis Pendidikan Pra Sekolah Anak dan Tingkat Pendidikan Orang Tua. Jurnal Psikologia, 1.

Susanto., Ahmad. (2011). Perkembangan Anak Usia Dini. Prenamedia Group.

Wahyuni, S. (2017). Kesiapan Bersekolah Anak Taman KanakKanak Kelompok B Ditinjau dari Lembaga Pendidikan dan Tingkat Pendidikan Orang Tua. 7(4). 
Al-Mudarris : Jurnal Ilmiah Pendidikan Islam

p-ISSN: 2622-1993

Vol. 3, No. 1, Mei 2020, pp. 1-20

e-ISSN: 2622-1586 